\title{
Switch to Sustainable Organic Tea Cultivation in the Eastern Black Sea Region of Turkey
}

\author{
Emine Yurteri \\ Field Crops Department, Faculty of Agriculture and Natural Sciences, \\ Recep Tayyip Erdogan University, PO box 53300, Rize, Turkey \\ E-mail: emine.yurteri@erdogan.edu.tr \\ Aysel Ozcan \\ Field Crops Department, Faculty of Agriculture and Natural Sciences, \\ Recep Tayyip Erdogan University, PO box 53300, Rize, Turkey \\ E-mail: aysel.ozcan@erdogan.edu.tr \\ Fatih Seyis (Corresponding author) \\ Field Crops Department, Faculty of Agriculture and Natural Sciences, \\ Recep Tayyip Erdogan University, PO box 53300, Rize, Turkey \\ E-mail: fatih.seyis@erdogan.edu.tr
}

\begin{abstract}
Organic tea production is an arising issue in the last one decade in Turkey. The biggest actor in the tea sector CAYKUR initiated organic tea farming specially in Rize since 2007. But in all tea production areas in Turkey, namely the villages Rize, Trabzon, Artvin, Giresun and Ordu there are initial work about possible switch to organic tea farming. The biggest advantages of these villages are that chemicals are not applied against pests and diseases. With the switch from chemical fertilizers to organic fertilizers the way to organic tea farming can be initiated. Only a few research about the use of organic fertilizers in this tea plantation areas were initiated. İn this study the changeover to sustainable organic tea production in Turkish tea plantations will be discussed.
\end{abstract}

Keywords: tea, organic agriculture, sustainable agriculture

DOI: $10.7176 / \mathrm{JSTR} / 5-9-06$

\section{Introduction}

In organic farming the use artificial components such as chemical fertilizers or pesticides is not allowed and therefore this production system is viewed as an eco-friendly production system, of course basing on sustainable productivity. Some people are talking about that their ancients actually performed organic farming. This is only partly true, because nowadays organic farming has to follow specific regulations. Organic farming is a licensed system aiming soil fertility, plant health and food security. All of this issues has to be monitored and registered by a variety of means.

As we know wrong conventional agriculture applications are degenerating the ecological balance. Rehabilitating this degenerated ecological balance is the primary aim of organic agriculture. Agricultural inputs should be minimized, applications degenerating this balance known for their harmfulness for human health should be avoided (Kayahan, 2001; Kirazlar, 2001).

Turkish tea gardens are located in the Rize province in the Northeast part of Turkey at the Black Sea Region. Present climatic conditions displaying snow in the winter and plenty of rain in the summer are ideal for tea growing. Turkey has a very young tea production history compared with the world, but the tea sector arise to a economically important in almost 80 years. İn the last 10 years organic tea cultivation become an important issue and efforts for developing a sustainable tea production was started.

\section{Sustainable Agriculture:}

The goal of sustainable agriculture can be defined as meeting society's food and textile needs in the present without compromising the ability of future generations to meet their own needs (Feenstra, 2011). 
There are many practices commonly used by people working in sustainable agriculture and sustainable food systems. The main aim of growers in sustainable agriculture is the promotion of soil health, minimization of water use, and lower pollution levels on the farm, which is maliar to organic plant production. On the other hand, organic tea cultivation aims to preserve plantations on ecological level, so maintaining present ecology and natural habit of course without contaminating soil, air and water. Of course this leads to maintainance of sustainable tea production (Meena, 2014). In this system tea has to be produced without the use of chemicals and chemical fertilizers.

Soit can be said, if Turkey focusses its direction on sustainable organic tea production, it will be an effective way regarding the bias against organic tea production and will solve the problems due to intensive chemical fertilizer applications.

\section{History of Organic Tea Farming in Turkey:}

Camellia sinensis, the most consumed beverage after water, belongs to the Theaceae family. Camellia sinensis leaves and leaf buds are used for manufacturing. Different types of tea, namely green, Oolong and black tea are three types of tea. Regarding fermentation Oolong tea is semi-fermented, green tea undergoes no any fermentation and and black tea is totally fermented (Rahman et al., 2013). In the world's total tea production black tea plays an important role with $72 \%$ (Sharangi, 2009). In Turkey, generally black tea is produced and green tea production is practised at small quantities.

In the second half of the 20th century industrial revolution and green revolution becomes famous and this led to a change in the direction of agriculture (Aksoy, 2001). The main aim in the Green Revolution was basically the compensation of the food need of the human population by increasing yield per unite area. The to be obtained and desired yield advance was achieved by using pesticides and fertilizers. But with the time negative effects of applicated pesticides and fertilizers was detected specially for human health. Further, the physical construction and nutritive stability of the soil degenerated and salinization and desertification come in sight. Due these reasons and other unfavorable developments "Organic Agriculture" comes to sunshine as an alternative production system.

Due to related and arising problems with chemical fertilization in Turkey organic farming developed and is developing rapidly. The first reason for this can be named as the demand for organic tea products especially from other countries. This issue is also considered by the Ministry of Agriculture, Food and Livestock and related universities, research companies and non governmental institutions. Further, the bias against chemical fertilizers led to a interest by local farmers and public opinion arise which has led also to the establishment of local market etc. (Aksoy \& Altındişli, 1999; Kenanoğlu \& Karahan, 2002; Demiryürek et al., 2008).

To feed the increasing human population the main aim has been the increase of yield of per unite area and this can be achieved in agriculture using fertilization. The kind of fertilizers used for this goal can be very different. The most known are organic and chemical fertilizers. If we talk about organic fertilizers we will remember farm manure which is natural and of organic character. Because chemical fertilizers are synthesized they can contain one or much more nutritive elements. If chemical fertilizers are used intensive negative effects could occur, which are determined by conducted experiments (Demiryürek, 2011).

In Turkey tea production is mainly located in the cities Rize, Ordu, Giresun, Trabzon and Artvin at the Black Sea Region (Anonymous, 2015). In the world, tea production is located at the equatorial region or around it, but in Turkey tea regions are located compared with the world at a top zone. In Asian countries tea production covers the whole year, but in our country where four climates can be met tea production is limited with six months because of snow in the winter period.

Beginning from the first tea production in Turkey our farmers did not use any pesticides in tea cultivation. The most important reason for this is that winter conditions decease pests in natural mean. Correspondingly there existed no need for any use of pesticides. We know that in organic tea production any use of pesticides and chemical fertilizers is not allowed. Therefore, if Turkey can switch to the use of organic fertilizers organic tea cultivation can be started and this a great advantage for Turkey (Sakl, 2011)

\section{Organic Tea Production in Turkey}

In Turkey organic tea farming was initiated by ÇAYKUR in 2003. Because of their suitability Borçka in Artvin and Çamlıhemşin and Hemşin in Rize were announced as potential areas. İn 2006 the "Organic Tea Farming Commission" was established to organize organic tea farming and production studies and to develop a road map for organic tea in Turkey (Seyis et al., 2018). Finally 2007 organic tea production started in Turkey with 135 farmers covering 37.8 ha (Table 1. 
Table 1: Organic Tea Production Areas in Turkey

\begin{tabular}{|l|c|c|}
\hline Years & Number of Farmers & Organic Tea Production area (ha) \\
\hline 2007 & 135 & 37.8 \\
\hline 2008 & 400 & 10.8 \\
\hline 2009 & 1.434 & 355.8 \\
\hline 2010 & 1.438 & 355.5 \\
\hline 2011 & 1.448 & 355.7 \\
\hline 2012 & 3.843 & 113.0 \\
\hline 2013 & 9.758 & 287.7 \\
\hline 2014 & 11.155 & 325.1 \\
\hline 2015 & 11.224 & 346.7 \\
\hline 2016 & 11.786 & 380.3 \\
\hline 2017 & 11.943 & 388.1 \\
\hline 2018 & 11.830 & 385.2 \\
\hline
\end{tabular}

Anonymous (2018)

Over years the number of farmers engaged with organic tea production increased rapidly up to 2014 and in 2018 about 11.830 are involved in organic tea production. Organic tea production area on the other hand increased up to 385.2 ha in 2018 .

Table 2: Organic Tea Leaf Production and Produced Tea Amounts (tonnes)

\begin{tabular}{|l|r|r|r|r|}
\hline \multirow{2}{*}{ Years } & \multicolumn{2}{|c|}{ Processed Tea (tonnes) } \\
\cline { 2 - 5 } & Bought Wet Tea (tonnes) & Black Tea & Green Tea & \multicolumn{1}{|c|}{ Total } \\
\hline 2009 & 361 & 58 & 3 & 61 \\
\hline 2010 & 384 & 152 & 5 & 157 \\
\hline 2011 & 1.743 & 313 & 13 & 326 \\
\hline 2012 & 1.724 & 339 & 10 & 349 \\
\hline 2013 & 1.732 & 353 & 9 & 362 \\
\hline 2014 & 1.927 & 341 & 26 & 367 \\
\hline 2015 & 7.381 & 1.328 & 21 & 1.349 \\
\hline 2016 & 22.330 & 4.449 & 39 & 4.488 \\
\hline 2017 & 25.509 & 4.995 & 9 & 5.004 \\
\hline 2018 & 30.000 & 5.777 & 2 & 5.779 \\
\hline
\end{tabular}

Most of the organic tea production is black tea (Table 2). Up to 2016 about 39 tonnes of processed green tea was common, but in the last two years green tea productin decreased to 2 tonnes.

The Muratlı district in Artvin; Hemşin, Çamlıhemşin, İkizdere, Tunca district, Senoz basin in Çayeli, higher altitudes of Pazar and Ardeşen, a part of the Çağlayan basin in Fındıklı, two settelements in Of/Trabzon, two settlements in Rize center and 1 settlement in Kalkandere are involved in organic tea farming in East Turkey.

The selected regions are rich in water resources. They are relatively young tea plantations and are located in upper altitudes. These tea plantations are surrounded by forests, only tea cultivation is present. Running waters, low settlement and industrialization are typical characteristics. Air, water and soil pollution due to industrialization is not present. This means ecotourism with the preservation of their historical tissue and presence of hot spring and baths (Yurteri et al., 2019). In 2009 a tea factory was built in the Hemşin district was opened as "Hemşin Organic Tea Factory".

To support the initiation of organic tea production ÇAY-KUR has taken some measures. From the beginning of the organic tea production ÇAYKUR decided to purchase all produced organic tea. Further, a. no quota or limitations, b. the price has to be earlier payed compared with conventional tea, c. $50 \%$ support for organic fertilizer, $d$. farmer commodities has to contact fertilizer companies and e. seminaries concerning fertilizer and fertilisation should be attend (Anonymous, 2018).

\section{Pro and Contra for Organic Tea Production in Turkey}

If wee look behind we can see that organic tea production is very young in Turkey. 2007 is the starting year in the Hemşin Valley, Rize and further regions followed. Because of the rapid increase of number of famers and production area the organic tea production issue will have a positive future in Turkey. 


\subsection{Pro's for organic tea production (Anonymous (2018):}

1- Suitability of ecological conditions

2- Winter conditions suppresses the development of fungi and destroying insects

3- $\quad$ No yield or quality losses caused by tea specific diseases and pests up to now.

4- No demand for chemicals for crop protection

5- Absence of air, soil and water pollution caused by heavy industry

6- Sufficient technical information and equipment by side of ÇAYKUR

7- Support from local administratives and non-governmental institutions because of possible contribution to tourism and regional development

8- İncrease in income level of farmers by supports and different price applications:

9- Demand for organic tea in the organic market is high

10- The shelf price of organic products are higher compared with conventional products

11- Tea waste obtaied from tea factories can be used as organic fertilizers,

12- The organic tea factory will help to improve the economy of the region

\subsection{Contras for organic tea production in Turkey:}

\subsubsection{Recommodation of suitable organic fertilizers does not exist}

The farmers do not use any kind of organic fertilizer in corresponding regions therefore yields are low. Unfortunately there is a lack in the recommendation of organic fertilizers. Studies based on the use of organic fertilizers in tea production will hopefully solve this problem in near future.

\subsubsection{Misunderstanding that switch to use of organic fertilizers will decrease obtained yield}

Due to wrong applications, there is a misunderstanding that the use of organic fertilizers will led to yield decrease. But in the example Hemşin organic fertilizers are not used and because of corresponding yield losses the gossip arised that yield losses will company organic tea production. Obtaining results from scientific studies will be helpful in this manner (Seyis et al., 2018)

\subsubsection{Intensive nitrogen fertilization and corresponding problems}

During the last decades farmers intensively used chemical fertilizers and this led to pollution of soil and environment. Assumely, the switch to organic tea production will take time and needs another approach in such regions.

\section{Organic Fertilizer Studies in Tea Plantations in Rize}

With the start of organic tea production some fertilizer studies were conducted, but due to our knowledge no recommadations ocur. ÇAYKUR planned to expand organic tea production areas and this the first step was the collobaration between ÇAYKUR, the Ministry of Agriculture, Food and Livestock and the Recep Tayyip Erdoğan University in 2017. The main and primary goal was to determine organic fertilizers suitable for organic tea cultivation.

In 2017 the first real scientific research was conducted using field experimental design. Different organic fertilizers were compared in a randomized block design with three replications at different locations, namely Çamlı and Pınarlı/Hopa, Fındıklı, Ardeşen, Pazar, Çayeli, Ortapazar and Of/Trabzon (Seyis et al., 2018). Two years results showed that soil pH increased and that some organic fertilizers were competitive with chemical fertilizer. Only after obtained 3 year results any fertilizer could be recommended for organic tea production.

\section{Future of Organic Tea Production in Turkey}

Due to intensive chemical fertilizer use the $\mathrm{pH}$ of soils decreased over years and with accompanying yield reduction farmers increased their fertilizer inputs up to achieving the former yield level, which has led also to additive decrease in soil $\mathrm{pH}$. But as shown before with the use of organic fertilizer/s the soil $\mathrm{pH}$ could be improved and tea plants could profit more from soil nutrients. Results from conducted organic fertilizer studies in tea plantations also revealed that phenolic content and antioxidant activity values of white tea (Yurteri et al. 2018), antioxidant activity of green tea (Özcan et al., 2017) could be increased with organic fertilizer. On the other side use and Seyis et al. (2017) showed that organic fertilizer applications give sufficient yields compared with chemical fertilizer.

Tea has a very short history in Turkey compared with tea planting countries in the World. But it seems that local farmers are familiar with this plant since centuries. Tea is still the biggest income of farmers in this region and the higher prices given for organic tea, the demand for healthier products and consumption by citizens gives a strong base for future organic tea production facilities, which is forming a base for sustainable organic tea production.

42 | P a g e 


\section{Conclusion}

Producing organic tea in Turkey is possible and this is an advantage and important opportunity for our country. Nowadays healthy consumption is an rising issue in Europe and in the World as well as Turkey. As all basic instruments are available in Turkey all tools should be initiated to switch to organic production Turkish tea plantations in near future. If organic tea meets the high price in the market this will eliminate the problem of competition of Turkish tea due to high costs. Further, if organic tea production sustained, the factories will have the opportunity to purchase tea from farmers with higher prices and this will led to the harvest of fresh tea leaves with higher quality (Sakl1, 2011).

ÇAYKUR planned to declare all tea plantations in Rize as Organic Tea Production areas in 2018. Conducted experiments gives some clue about the kind of organic fertilizers, but if we remember that about 835 ha tea production area is present still questions are staying in the room how the necessary amount of needed organic fertilizer has to be produced. Organic agriculture is a lifestyle, therefore tea farmers should intensively educated with organic tea production. The most important issue is that the tea farmers has to be highlighted about future plans of regarding organic tea cultivation in Turkey, if a sustainable organic tea production is targeted.

\section{References}

Aksoy, U. (2001). Ecological Agriculture: General Overview. Turkey 2. Ecological Agriculture Symposium. 14 - 16 November, Antalya, NAR - SER ve ETO. TKB Tarım 2000 Vakfi Yayınlarl, Ankara, s.3 10.

Aksoy, U. \& Altındişli, A. (1999). Production, export and improvement possibilities of ecological agriculture products in the world and Turkey. Istanbul Ticaret Odası Yayınları, Yayın No: 199970. İstanbul, $125 \mathrm{~s}$.

Anesini, C., Ferraro, G.E. \& Filip, R. (2008). Total polyphenol content and antioxidant capacity of commercially available tea (Camellia sinensis) in Argentina. Journal of Agricultural and Food Chemistry, 56: 9225-9229.

Anonymous (2015). Turkish Tea Sector. Actual Situation Report. Rize Commodity Exchange.

Anonymous (2018). Statistical Bulletin. ÇAYKUR

Demiryürek, K., Stopes, C.\& Güzel, A. (2008). Organic Agriculture: The Case of Turkey. Outlook on Agriculture, 37 (4): 7-13.

Demiryürek, K. (2011). The Organic Agriculture Concept Organic Agriculture in Turkey and the World. GOÜ Ziraat Fakültesi Dergisi, 28(1): 27 - 36.

Feenstra G (2011). UC Sustainable Agriculture Research and Education Program, University of California, Davis, CA 95616, (530) 752 - 7556

Kayahan, H.S. (2001). Development of domestic market in ecologic agriculture. Turkey 2. Ecological Agriculture Symposium, 14-16 November, Antalya, NAR-SER ve ETO. Ankara: TKB Tarım 2000 Vakfi Yayınlart: 24-29.

Kenanoğlu, Z. \& Karahan, O. (2002). Policy Implementations for Organic Agriculture in Turkey. British Food Journal, Vol. 104(3-5): 300-318 (19).

Kirazlar, N. (2001). Legislation of Ecological (Organic) Agriculture. Turkey 2. Ecological Agriculture Symposium, Symposium Book, p. 11 - 19.

Meena, H. P. (2014). Organic Farming: Concept and Components. Popular Kheti. 1. 5-14.

Özcan, A., Yurteri, A. \& Seyis F. (2017) Determination of th effect of chemical and organic fertilizers on the antioxidant activity of green tea (Camellia sinensis L.). The Second Japan - Turkey International Symposium on Pharmaceutical and Biomedical Sciences, p.63.

43 I P a g e 
Rahman, M. M., Kalam, M. A. \& Islam, M. M. (2013). Change of Chemical Compositions in Semifermented Tea on Land Elevation. African Journal of Agricultural, 8(25): 3224-3228.

Sakl1 A. (2011). A Critical Review of Recent Sectoral Structure Proposal for Turkish Tea Sector. Humanity \& Social Sciences Journal, 6 (1): 01-07.

Seyis F. , Yurteri E. , Özcan A. \& Şavşatli Y. (2018). Organic Tea Production and Tea Breeding in Turkey: Challenges and Possibilities. Ekin Journal of Crop Breeding and Genetics, 4: 60-69.

Sharangi, A. B. (2009). Medicinal and Therapeutic Potentialities of Tea (Camellia sinensis L.)-A Review. Food Research International, 42 (5-6): 529-535.

Seyis F. , Yurteri E. , Özcan A. Terzioğlu İ. \& Şavşatli Y. (2017). Doğu Karadeniz Organik Çay Tarımı Çalışmaları", 1st International Symposium on Organic Agriculture and Biodiversity (Otbiyosem), BAYBURT, TÜRKIYE, 27-29 Eylül 2017, pp.27-27

Yurteri E. , Özcan A. , Seyis F. (2019). Tea (Camellia sinensis) Cultivation and Breeding in Turkey: Past and Present Status. Ekin Journal of Crop Breeding and Genetics, 5: 111-119.

Yurteri, E., Özcan, A., Seyis, F., Yurteri, T. (2018), Determination Of The Effect Of Different Fertilizer Doses and Diffeent Drying Methods On Total Phenol Content and Antioxidant Activity of Organic White Tea (Camellia sinensis L.). The Second Japan - Turkey International Symposium on Pharmaceutical and Biomedical Sciences, p.62. 